\title{
Supporting lecturers to demystify learning in a science faculty
}

\section{Louw, Ina}

Department for Education Innovation, University of Pretoria, South Africa.

\begin{abstract}
Pedagogical competence is not always part of the skills set of science educators at research intensive universities. Thus, the Academic Developer $(A D)$ in the Faculty of Natural and Agricultural Sciences (NAS) at the University of Pretoria makes use of the Pedagogical Competence Model in order to help develop lecturers' pedagogical competence. The overall aim of the study is to support lecturers to have a clear focus on student learning; assist them to development their pedagogical skills over time; and to adopt a scholarly approach to teaching and learning. Peer reviews are compulsory for probation candidates (newly appointed) as well as staff applying for promotion. In 2017 a total of 58 lecturers were reviewed by the AD, and 26 of these lecturers completed an online questionnaire that was intended to establish the influence the AD's reviews had on their teaching practices. Subsequently interventions were planned aligned to the perceived needs for development. The project is still in progress, but results from the 538 members who already received training during 2018 indicate improved understanding of student learning and great appreciation for the support.
\end{abstract}

Keywords: Science education, pedagogical competence, continuous professional development, student learning. 


\section{Background}

The University of Pretoria (UP), a research intensive university in South Africa, has adopted a hybrid teaching approach and lecturers are expected to augment face-to-face lectures with online material. However, not many lecturers have knowledge about learning styles, learning theories, questioning- or engagement techniques. Thus, the Academic Developer (AD) in the Faculty of Natural and Agricultural Sciences (NAS) at the University of Pretoria conducts training workshops and presents lectures in order to help develop lecturers' pedagogical competence.

At UP every academic staff member needs to submit a teaching portfolio when they reach the end of their probation period or when they apply for promotion. A peer review is part of that portfolio and it involves a class visit from the $\mathrm{AD}$ on invitation from the lecturer. The $\mathrm{AD}$ does an observation based on an observation sheet with pre-determined aspects, such as how: the mood is set during the introduction, connections are made to prior knowledge and the big picture, students are motivated, students are engaged, and how learning is monitored, and finally how the conclusion of the lecture is conducted. The AD then compiles a written report and shares it with the lecturer. Suggestions for improvements are discussed and follow-up visits are arranged where needed.

The $\mathrm{AD}$ also conducts training sessions to guide the compilation of a teaching portfolio and that offers an ideal opportunity to share educational principles such as learning styles, learning theories and classroom management skills in a stealthy way. The combination of practical advice from the peer reviews and theoretical advice during the writing of their teaching portfolios allows the AD to tailor her training based on actual needs (see Table 1). The AD is aware of the fact that teaching practice can be hard to change (Olsson, 2015), but through personal involvement and enthusiasm from her part, as well as making it practical the possibility is increased that conceptual change strategies can "become part of teachers' normal routines" (Duit \& Treagust, 2003: 684).

Although the Academic Developer (AD) supports lecturers in their teaching capacity, the extreme pressure to perform in their research outputs, often causes lecturers to not recognise the need, or make the time to receive assistance. Therefore, in order to ensure that the lecturers participate, the Deputy Dean for Teaching and Learning in the Faculty of Natural and Agricultural Sciences suggested continuous professional development aiming at the attendance of sessions on teaching skills to be included as one of the key performance indicators for lecturing staff. The Academic Developer has suggested a list of topics to train and support lecturers individually and in departmental contexts. This list is based on her observations during peer reviews of teaching that were conducted during $2017(n=58)$. 


\section{Theoretical Approach}

The theoretical framework for the project is based the Pedagogical Competence Model (Olsson \& Roxå, 2013), but adapted to the local context, see Figure 1. The theory component is the starting point for this project, because lecturers need some theoretical foundation. In the planning step, faculty members plan the implementation of the new knowledge in their classes, with the help of the AD. In the practice step they implement an intervention or changed strategy, supported by the AD and finally in the observation step they collect evidence about their students' learning and perceptions. They can collect data with questionnaires, focus group interviews and observations to interpret with the student grades.

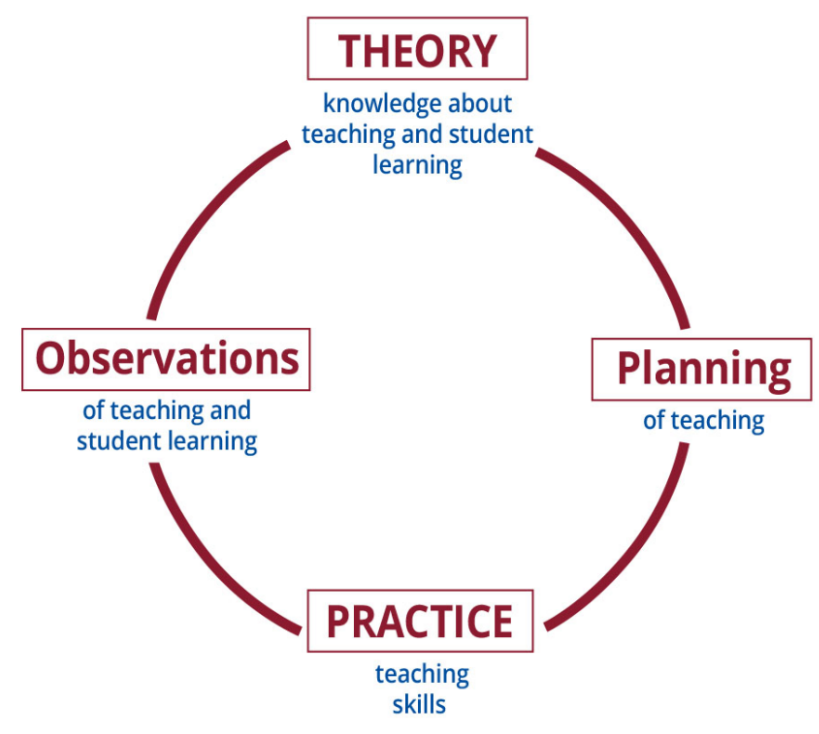

Figure 1. Pedagogical Competence Model. Adapted from Olsson and Roxå (2013).

\section{Methodological Approach}

\subsection{Phase 1: Conducting Peer Reviews}

The first set of data that informed the establishment of the project was collected from 58 peer reviews done in the faculty during 2017. Faculty members invited the AD to attend a lecture and the $\mathrm{AD}$ observed the lecture according to pre-set criteria that were known to the staff member. 


\subsection{Phase 2: Questionnaire to participants of peer reviews}

When 45 peer reviews were conducted, a questionnaire was sent out by the Deputy Dean to these colleagues to establish their perceptions about the experience. The instrument was in Qualtrics (online survey instrument) and included structured and open questions. We received 26 responses back $(58 \%)$.

\subsection{Phase 3: The Training Interventions}

The AD planned the training sessions to address the needs as identified during the peer reviews. The book by Ambrose, Bridges, DiPietro, Lovett \& Norman (2010) was used to facilitate sessions of "how learning works", and the work by Dweck (2006) was used to explain the importance of a growth mindset. The AD started training sessions in February 2018 (see Table 1). The following topics were presented, in different formats: 1) learning theories: in printed format via the Learning Management System (LMS) to supply theoretical knowledge; 2) "The art and science of presenting a lecture": presentation format, 3) writing good learning outcomes: as a workshop. Faculty members were required to sign up for the session(s) they wanted to attend, but can also request a specific session and format, such as a workshop to revise study guides for a particular program. The teaching assistants were also identified as a group that needs training and they are included in this project. 
Table 1. Table 1. Conducted training session between February and April 2018.

\begin{tabular}{|c|c|c|c|}
\hline Session & $\begin{array}{l}\text { Targeted } \\
\text { audience }\end{array}$ & $\begin{array}{l}\text { Number of } \\
\text { attendees }\end{array}$ & Data collection \\
\hline $\begin{array}{l}\text { Soft skills in tutorials and } \\
\text { practical sessions }\end{array}$ & $\begin{array}{l}\text { Student } \\
\text { assistants \& } \\
\text { demonstrators }\end{array}$ & $\begin{array}{l}246 \text { ( } 7 \text { depart- } \\
\text { mental } \\
\text { sessions) }\end{array}$ & Feedback form \\
\hline Compiling a teaching portfolio & Open to all & 48 (4 sessions) & Feedback form \\
\hline $\begin{array}{l}\text { Introduction to the CPD menu at } \\
\text { departmental meetings }\end{array}$ & $\begin{array}{l}\text { Departments } \\
\text { that invited } \\
\text { the AD }\end{array}$ & $\begin{array}{l}134 \text { ( } 6 \text { depart- } \\
\text { mental } \\
\text { sessions) }\end{array}$ & Feedback form \\
\hline $\begin{array}{l}\text { The art and science of presenting } \\
\text { a lecture for anyone }\end{array}$ & Open to all & 36 (2 sessions) & Minute papers \\
\hline How learning works (workshop) & $\begin{array}{l}\text { Newly } \\
\text { appointed } \\
\text { staff }\end{array}$ & 15 (2 sessions) & Feedback form \\
\hline How learning works (lectures) & Open to all & 42 (3 sessions) & Minute papers \\
\hline $\begin{array}{l}\text { Using the growth mindset for } \\
\text { learning }\end{array}$ & Open to all & 17 (1 session) & Minute papers \\
\hline Total: & & 538 & \\
\hline
\end{tabular}

Source: Constructed by author (2018).

The project is ongoing and new sessions will be added as the AD identified relevant topics or as requests are made by departments.

\section{Results}

The project has multiple phases and is a work in progress, but will now be discussed in terms of the phases that has been completed.

\subsection{Phase 1 Results}

Thematic analysis of the reports written by the AD revealed the need for development in the following areas listed in Table 2: 
Table 2. Areas identified for training

\begin{tabular}{|c|c|}
\hline Area & Perceived problem \\
\hline Structure of the lecture & No introduction or conclusion \\
\hline Learning outcomes & Not shared with students at all and poorly formulated \\
\hline Activating prior knowledge & Lack of prior knowledge not realised or managed \\
\hline Themes & $\begin{array}{l}\text { Not identifying and highlighting the big ideas in the } \\
\text { module }\end{array}$ \\
\hline Connections & Not assisting students to form connections \\
\hline Teaching style & $\begin{array}{l}\text { No clear indication that different learnings styles are } \\
\text { accommodated }\end{array}$ \\
\hline Monitor learning & $\begin{array}{l}\text { No attempt to monitor learning by including some } \\
\text { formative assessment activities }\end{array}$ \\
\hline Engagement & Lack of student engagement \\
\hline Class climate & $\begin{array}{l}\text { No attempt to create a positive class room climate/safe } \\
\text { learning space }\end{array}$ \\
\hline Relevance & $\begin{array}{l}\text { Work is not made relevant. No relevant examples are } \\
\text { used. }\end{array}$ \\
\hline Student questions & Not handled appropriately \\
\hline
\end{tabular}

Source: Constructed by author (2018)

The themes were recognized as basic pedagogical knowledge that was not in action in some lectures and an appropriate intervention was planned. It is worth mentioning that excellent examples of student engagement, use of clickers to monitor learning, positive class climate and group work were observed.

\subsection{Phase 2 Results}

The results from the questionnaire conducted with reviewed colleagues in Phase 2 were positive and encouraging. One participant said: "Meaningful time to reflect on my teaching practices with someone who understands student learning, which is something most lecturers have no clue about themselves". The results also indicated that there was trust placed in the $\mathrm{AD}$ as shown by the following quotation made by another colleague: "I realise that the $A D$ is busy. Follow-up sessions (even uninvited) would be appreciated and constant feedback on how to improve for the benefit of the students. Suggesting creative 
ideas on how to present 'boring' sections of the work to not only inspire the lecturer but to motivate the lectures to inspire the students." The comments in the survey assured the AD that the intervention is needed and welcomed.

\subsection{Phase 3 Results}

The results from Phase 3 were collected during each training event in the format indicated in Table 1. The teaching assistants $(n=246)$ completed a Likert scale (4-way) question about the six different topics discussed in the training and on average $91.6 \%$ marked the "valuable" or "absolutely necessary" options. The departmental introduction feedback had a 4-way scale as well (from strongly agree to strongly disagree) and 93\% chose the two agree-options indicating the training menu has a "variety of sessions" to choose from, similarly $92 \%$ voted positively that there are "more than one session they would like to attend". The fact that $75 \%$ indicated positively that "there are topics that they have never heard about" indicated the need for CPD.

The minute papers required the attendees to provide a response to the following question: "What have you learned today that you will implement in your lectures?" The participants mentioned that they would use minute papers to get their students' voices more regularly; they will utilize muddiest point papers to determine misconceptions; make an effort to connect topics to the big picture; and actively ensure that students' prior knowledge is appropriate and correct, instead of assuming it is relevant. Some mentioned that they will negotiate ground rules for their groups in an effort to create a safe classroom environment. They also plan to motivate students more deliberately, by using some examples from the training sessions. Many realised for the first time how important timely feedback is for learning. Some of the quotes are shared in Table 3. 
Table 3. Quotes from the training sessions

\begin{tabular}{|c|c|}
\hline Session & Quote \\
\hline Student assistants & $\begin{array}{l}\text { The session was amazing. It was a fresh perspective of } \\
\text { the importance of the tutor and the well-being of the } \\
\text { student. }\end{array}$ \\
\hline $\begin{array}{l}\text { Workshop for newly } \\
\text { appointed faculty members }\end{array}$ & $\begin{array}{l}\text { Enthusiastic, lively, engaging and knowledgeable. She } \\
\text { knew the content and transferred her knowledge very } \\
\text { well. }\end{array}$ \\
\hline $\begin{array}{l}\text { Session on "How learning } \\
\text { works" }\end{array}$ & $\begin{array}{l}\text { Really organized \& showing teaching as a science and } \\
\text { gives very useful and practical tips about how to } \\
\text { conduct learning. }\end{array}$ \\
\hline $\begin{array}{l}\text { Session on the growth } \\
\text { mindset }\end{array}$ & $\begin{array}{l}\text { You gave me more ideas to improve myself first! Thank } \\
\text { you. }\end{array}$ \\
\hline $\begin{array}{l}\text { Session on the art and } \\
\text { science of presenting }\end{array}$ & $\begin{array}{l}\text { I learned the importance of audience engagement and } \\
\text { that my lecture should build suspense and be relevant to } \\
\text { students. } \\
\text { ource: Constructed by author (2018) }\end{array}$ \\
\hline \multicolumn{2}{|l|}{ 5. Conclusion } \\
\hline \multicolumn{2}{|c|}{$\begin{array}{l}\text { The potential significance of the work is that lecturers are becoming aware of the fact that } \\
\text { their students are millennials (Nevid, 2011) with a short attention span, (Furner, Yahya \& } \\
\text { Duffy, 2005) and a need for immediate results (Spary, 2015). The importance of prior } \\
\text { knowledge was recognized as important in the diverse student population (Ambrose et. al. } \\
\text { 2010). The importance of timely feedback in the forming of neural connections were } \\
\text { understood (Jensen, 2005:53) and I created an awareness about the "growth mindset" as } \\
\text { explained by Dweck (2006). Lecturers need to understand what the growth mindset entails } \\
\text { and support their students in creating growth mindsets and to develop grit (Duckworth \& } \\
\text { Gross, 2014). Lecturers will hopefully experience noticeable positive change in their } \\
\text { pedagogical competence and job satisfaction. This in turn should impact positively on } \\
\text { student engagement and learning, perhaps achieve better class attendance and improved } \\
\text { retention. }\end{array}$} \\
\hline
\end{tabular}




\section{References}

Ambrose, S. A., Bridges, M. W., DiPietro, M., Lovett, M. C., \& Norman, M. K. (2010). How learning works: 7 research-based principles for smart teaching. San Francisco: Jossey-Bass.

Duckworth, A., \& Gross, J. J. (2014). Self-control and grit: Related but separable determinants of success. Current Directions in Psychological Science, 23(5), 319-325.

Duit, R., \& Treagust, D. F. (2003). Conceptual change: A powerful framework for improving science teaching and learning. International Journal of Science Education, 25(6), 671-688.

Dweck, C. S. (2006). The new psychology of success: How we can learn to fulfil our potential. New York: Ballantine Books

Furner, J. M., Yahya, N., \& Duffy M. L. (2005). Teach mathematics: Strategies to reach all students. Intervention in school and clinic, 41(1), 16-23.

Jensen, E. 2005. Teaching with the brain in mind, $2^{\text {nd }}$ ed. Virginia: Association for Supervision and Curriculum Development.

Langa, M.(Ed.). (2017). \#Hashtag: An analysis of the \#FeesMustFall Movement at South African universities. Retrieved November 10, 2017 from https://www.csvr.org.za/pdf/An-analysis-of-the-FeesMustFall-Movement-at-SouthAfrican-universities.pdf

Nevid, J. (2011). Teaching the millennials. Retrieved November 8, 2017 from https://www.psychologicalscience.org/observer/teaching-the-millennials

Olsson, T. (2015). A Model Promoting the Scholarship of Teaching and Learning in Higher Education. Quality Enhancement Project: Workshop, Durban, 1-2 June.

Olsson, T., \& Roxå, T. (2013). Assessing and rewarding excellent academic teachers for the benefit of an organization. European Journal of Higher Education, 3(1), 40-61.

Schön, D. A. (1987). Educating the Reflective Practitioner. San Francisco: Jossey-Bass.

Spary, S. (2015). Millennials' demand for instant gratification is shaping the future of retail. Retrieved October 8, 2017 from https://www.campaignlive.co.uk/article/millennialsdemand-instant-gratification-shaping-future-retail/1331511

Tsai, C-C. (2004). Conceptions of learning science among high school students in Taiwan: a phenomenographic analysis. International Journal of Science Education, 26(14), 1733-1750.

Zuber-Skerrit, O. 2015. Action research. In O. Zuber-Skerritt, M. Fletcher, \& J. Kearney, Professional learning in higher education and communities: Towards a new vision for action research (pp 102-133). London: Palgrave. 